\title{
Implementation of Cyber-Physical-Social System Based on Service Oriented Architecture in Smart Tourism Case Study: Bandung Natural Tourism
}

\author{
Ilham Firman Ashari \\ Teknik Informatika, Institut Teknologi Sumatera \\ firman.ashari@if.itera.ac.id
}

\section{Article Info \\ Article history: \\ Received 2020-05-30 \\ Revised 2020-06-04 \\ Accepted 2020-06-22}

Keyword:

cyber-physical-social system, service engineering framework, service oriented architecture, smart tourism

\begin{abstract}
One of the biggest attractions in the tourism industry in Bandung is nature tourism. There is still such a constraint related to get information about nature tourism in Bandung because new attractions in Bandung always appear every year. This is felt particularly for foreign tourists outside of Bandung. Tourists are still confused to find new and popular tourist attractions, which are places that are worth visiting or not. By implementing Cyber-Physical-Social System (CPSS) with a new approach that is emphasized on social aspect in smart tourism based on Service Oriented Architecture (SOA) as methodology can influence other travelers to visit tourist attractions in Bandung. The main results are tourists will get information such as location, route, images, rating, captions of tourist attractions, and the most important thing is to be able to exchange information with others. Smart tourism is more flexible because it is web based and does not depend on the operating system used, does not require database storage, does not take up storage space, and is free. Tourists can access smart

tourism anytime and anywhere.
\end{abstract}

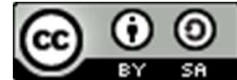

This is an open access article under the CC-BY-SA license.

\section{INTRODUCTION}

Tourism industry in Indonesia has become one of the most important sectors especially in natural and cultural tourism [1]. The current government has established several priorities for national development programs, which one of the programs is to improve tourism [2] involving information technology. According to Dadang Rizki Ratman, Deputy of Tourism and Investment Development of the Ministry of Tourism Indonesia, revealed that today's tourism is the key to development, prosperity, and happiness [2]. However, with the great potential of diverse natural and cultural resources, the achievement of Indonesian tourism not yet optimal [3].

Indonesian tourists now expect the quality of tourism services to increase [4]. Not only domestic tourists but also foreign tourists expect the tourism system can provide better services. With an integrated online system, tourists can access travel information anytime, anywhere, and can exchange information with other tourists [5].

Bandung is one of the popular tourist destinations in the region of West Java. One of the biggest attractions of the tourism industry in Bandung is nature tourism [6]. With such potential, Bandung can become a contributor to the tourism industry in Indonesia. In addition, Bandung has the advantage of the natural beauty and abundance of tourist places of interest [6]. However, there is still such a constraint related get detail information about nature tourism in Bandung. This is felt particularly for foreign travelers or tourists outside of West Java. Tourists usually seek and find information through the search engine. This method is not effective and efficient, because the information shown is less complete. Usually the information presented does not display the feedback or rating of the user or other travelers who have visited, so it will be difficult to determine whether these sights worth a visit or not.

"Smart Tourism" inherit from "Smart City", as a platform which integrates tourist sites and technology to provide attractive and real-time information by observing user behavior, and aspects involved such as cloud computing, internet of things, so it can provide good service about the tour places to the user [7][8]. Tourists usually need locations and routes to tourist places, the most frequently used services are services provided by geographic information systems (GIS), such as mapping, geocoding, and geotagging [9]. Since the need of real time information and interaction in the field of tourism improved, social interaction factor should be included 
in the design of smart tourism.

Roy proposed "Visit Samosir" based on a mobile application that runs on the android operating system that is used to provide tourist information on samosir regency [10]. The data used is taken from the local database and then displayed to the user. Application users can share information to Facebook.

Joseck et. al. proposed "M-Tour", which is a smart tourism based on mobile applications for the recommendation of tourist attractions [11]. Research undertaken by Joseph et al. is related to how to provide applications that facilitate interaction between several stakeholders in providing tourist information. "M-Tour" does not use CPSS to retrieve tourist information, where information used on the system is based on a database entered by several stakeholders.

Most systems implement the concept of Cyber Physical systems (CPS). Aspects of the CPS are the cyber and physical. In CPS, there is no social aspect. CPS is not like embedded systems, where cps is designed as an element that interacts with physical input and output, not as a stand-alone device [12]. This work proposed the design of Smart Tourism using Cyber-Physical-Social System (CPSS) approach and involving Service Engineering Framework (SEF) based on Service Oriented Architecture (SOA) methodology.

CPSS integrates social aspects into CPS [13]. CPSS involves interactions between several aspects, such as physical, cyber, and social aspects, thus improving the quality of human life [14]. The service approach to CPSS is important besides being able to integrate, organize, and share information with humans [15]. CPSS concept is very usefull to optimize interaction between human system and how they interact each other. Several components such as sensors (GPS), IoT, cloud services, or simple as human are holds important role and could increase quality of the tourist experience [16].

SEF is useful not only in system development but also provides interaction systematic service design from web services, such as providing an understanding of the structure, design, implementation, deployment, documentation, operation of e-services [17][18][19]. SOA has the ability to bridge the needs of business processes with IT-based development processes and implement them as service components [20]. SOA is technical approach to redefine business processes of an organization as a set of services that can bridge the needs of the business process (BP) with technology information [21]. Complementing SEF with SOA should be an ideal approach for business services development to answer the competitiveness challenge and the demand for agility in the service.

The smart tourism system was developed can provide information about tour place in real time, displaying routes to tourist attractions appropriately, showing ratings of tourist destinations, and sharing information with other tourists through social media. This can make it easier to obtain tourist information and to improve the results of the recommendations provided by smart tourism. In addition, also can influence the decision making whether that particular attractions in Bandung to visit or not. The evaluation is done by assessing aspects related to CPSS whether these aspects have been implemented well, so that providing a good service to the users

\section{RESEARCH METHOD}

During the implementation of smart tourism based on CPSS, this research using Service Oriented Architecture (SOA) based on Service Engineering Framework as a methodology. The stages are Requirement Identification, design, development, and deployment. These four stages can be seen in (Figure 1).

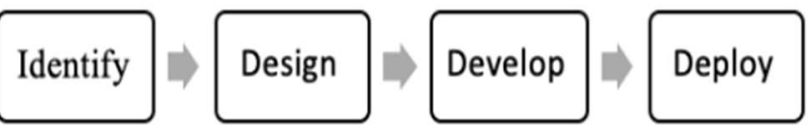

Figure 1. The Phase SEF based on SOA

\section{A. Requirement Identification}

The initial stage before identifying needs is to conduct an analysis of what problems are being experienced by local or foreign tourists related to tourism in Bandung. This is done by conducting a literature study and observation. According to data from the Central Bureau Statistics Indonesia, in 2018 the number of domestic and foreign tourists visiting Bandung was 1.8 million.

Department of Tourism and Culture targets the number of tourists in 2020 to reach more than 3 million people. In order for the tourist target to be met fastly in 2020, tourists must know the most popular tourist attractions, description of tourist attractions, tourist ratings, and routes to tourist attractions, thus increasing tourist interest to visit.

Because smart tourism is an implementation of CPSS, the sosial aspect should be utilized to improve the quality of recommended tourist attractions. To answer problems related to tourism in Bandung, it requires a service that can increase the existing tourism potential. The ways that can be done, that are:

- Collecting data from social media in real time using API twitter. Initially, the data obtained is in the form of JSON, then parsed so that information is obtained related to the user's name, caption tweet, date, location of the user when posting the tweet data, and the number of likes on the post. The data are taken from May 2020. The data that can be taken only contains photos, hashtag \#tourism, and \#bandung, as long as it meets these criteria, it is inevitable that the tweet data will be retrieved.

- Smart tourism that is created can filter out special tourist destinations in Bandung, which are related to nature tourism. Tourists can determine whether tourist attractions worth visiting based on tourist rating. Rating tourist attractions obtained from the number of like tweets posts from other users. 
- Share information through social media such as facebook and twitter. By exchanging information, users or tourists who want to travel to Bandung know the tourist attractions that are currently popular.

CPSS has three main aspects that are; cyber, physical, and social. The three aspects of CPSS on smart tourism can be seen in (TABLE I).

TABLE I

\begin{tabular}{|c|c|c|}
\hline \multicolumn{3}{|c|}{ CPSS ASPECT IN THE PROPOSED SYSTEM } \\
\hline Aspects & $\begin{array}{c}\text { Smart } \\
\text { Tourism } \\
\text { Components }\end{array}$ & Description \\
\hline Cyber & $\begin{array}{l}\text { - Internet } \\
\text { - Cloud } \\
\text { service } \\
\text { - Twitter API }\end{array}$ & $\begin{array}{l}\text { - Implementation of smart tourism } \\
\text { using web service that involved } \\
\text { internet access and cloud storage } \\
\text { - Twitter API is used to display } \\
\text { information related to natural } \\
\text { attractions, images, location } \\
\text { coordinates, and tourist routes. }\end{array}$ \\
\hline Physical & $\begin{array}{l}\text { - Sensors GPS } \\
\text { - Device/PC } \\
\text { - People / } \\
\text { twitter user }\end{array}$ & $\begin{array}{l}\text { - The system uses the GPS sensor } \\
\text { of the user's device to find out the } \\
\text { coordinates of the user's current } \\
\text { location and show the route to } \\
\text { tourist sites. } \\
\text { - Users can use their device or PC } \\
\text { to access smart tourism } \\
\text { - People or twitter user can act as } \\
\text { sensors that provide information } \\
\text { on tourist attractions from posts } \\
\text { on twitter and people can act as } \\
\text { actuators directing others to } \\
\text { tourist attractions. }\end{array}$ \\
\hline Social & $\begin{array}{l}\text { - } \text { Human } \\
\text { interaction } \\
\text { - Data from } \\
\text { twitter }\end{array}$ & $\begin{array}{l}\text { - The system provides facilities for } \\
\text { sharing tourist information } \\
\text { through social media such as } \\
\text { Facebook and Twitter } \\
\text { - Data from twitter is the main data } \\
\text { source used in smart tourism }\end{array}$ \\
\hline
\end{tabular}

\section{B. Design}

The design phase aims to find out the right service in accordance with the identification requirements described earlier. The main needs required are information related to tourist attractions in the form of descriptions of tourist attractions, tourist attractions, rating of tourist attractions, and sharing or exchanging tourist information. Use case diagram is shown on (Figure 2). The description of the flow of smart tourism when data are taken and data presented to users is illustrated using Business Process Model Notation (BPMN) as in the (Figure 3). The steps taken are:

1. Smart tourism will read the current user's position using the Google API. Previously, users must first activate the GPS feature of the device being used and web browser allow to know location user.

2. Google API will provide information in the form of latitude and longitude coordinates from the user, after that the user's location will be displayed, accompanied by a pin marker and coordinates.

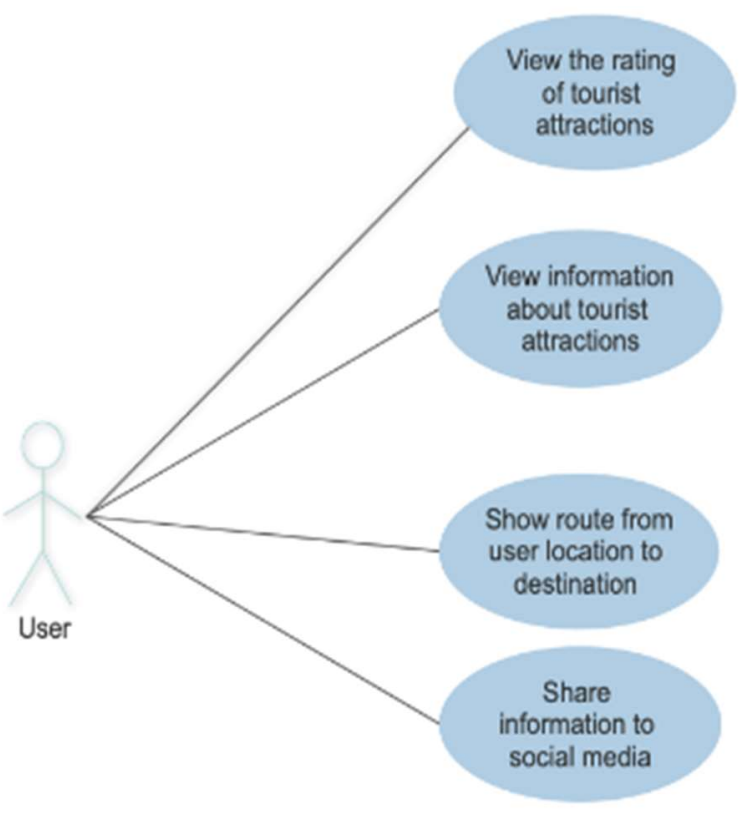

Figure 2. Use Case Diagram of Smart Tourism Application

3. Smart tourism displays all information related to tourist attractions using the Twitter API. To obtain access to the Twitter API, access rights must be obtained in the form of Tokens and Keys used as OAuth.

4. Tourist information displayed will be filtered based on several criteria. The first criterion is the hashtag \#wisataalam or \#bandung. The second criterion is images, information that is displayed on smart tourism is what contains images. With the pictures, the information displayed can be more interesting for tourists and show the existence of these tourist attractions. The third criterion is rating, where the rating is taken by the number of likes posted on the twiter.

5. Twitter API provides tourist location information based on the location of posts from users, this will be a tourist destination point or the existence of tourist attractions. To show the route of tourist attractions from the user's current location to the tourist destination, it is necessary to know the latitude and longitude of the user based on the Google API and the destination from the Twitter API. Users just click "LIHAT LOKASI" to show the route to tourist sites. Examples of user locations and routes to tourist attractions in (Figure 4). 


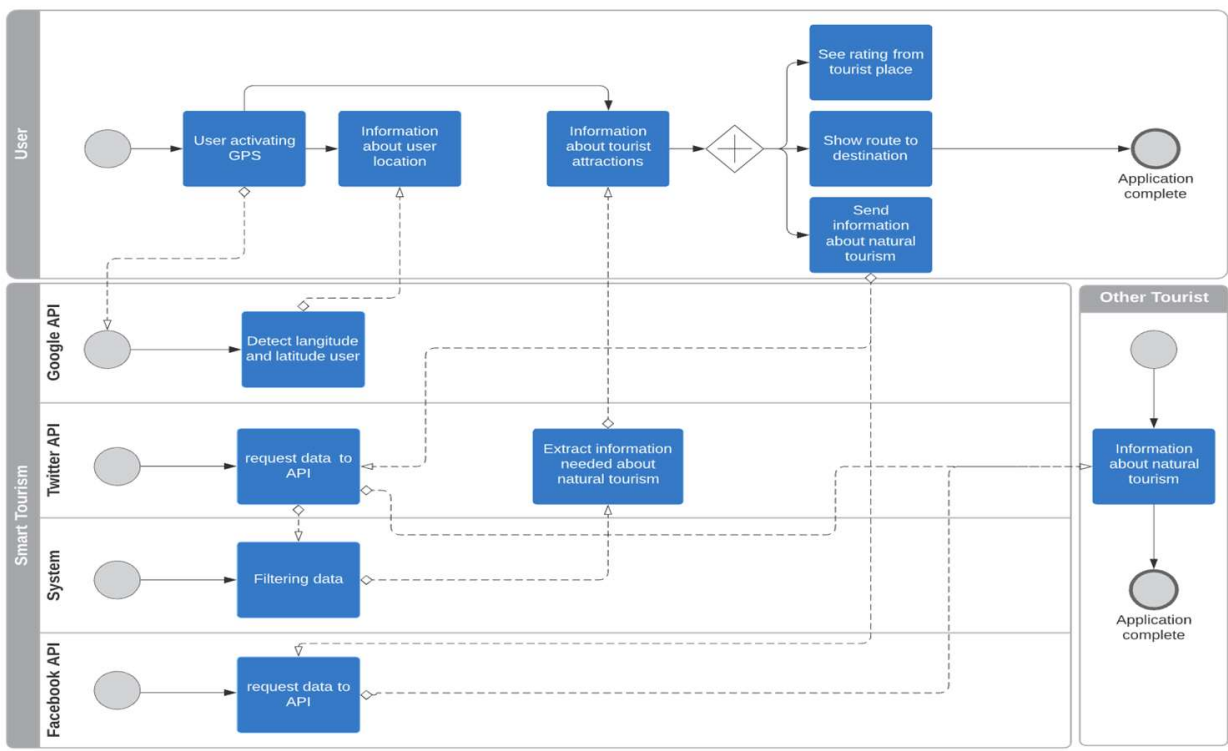

Figure 3. BPMN for smart tourism application

The most important social aspect here is being able to share information with other tourists. With smart tourism, tourists can share information via facebook and twitter. To connect smart tourism with facebook, facebook API is needed.

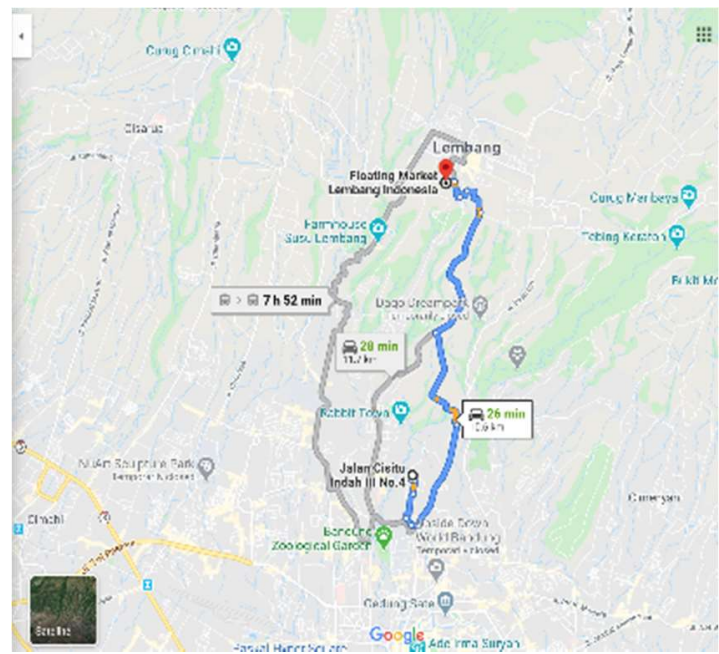

Figure 4. Route of the user's current location to travel destinations

\section{Development}

Smart tourism developed involves social aspects by implementing CPSS so that it can attract tourists and can increase the number of tourists who will visit. Smart tourism is developed based on web using PHP and javascript programming languages. In addition, to make the display more attractive and responsive, CSS is added, so that smart tourism can be accessed through several devices such as smartphones, phablets, tablets, and notebooks.

At the smart tourism development stage, smart tourism software architecture is created. Software architecture is the structure of a software system that consists of multiple components, showing characteristics externally from components, and describe the relationships between the internconnected components [22][23].

The following picture describes the process that defines the flow of a system that is built. So, it can be assessed whether each process is precise with the existing requirement and design. Here is an overview of the architecture of smart tourism can be seen in (Figure 5).

In (Figure 5), it is seen that the architecture of smart tourism consists of five layers. The top layer is smart tourism goals, the second layer is the service provided by smart tourism, the third layer is the value generation, the fourth layer is the business imperative, and the fifth layer is related to the use of technology for provide services.

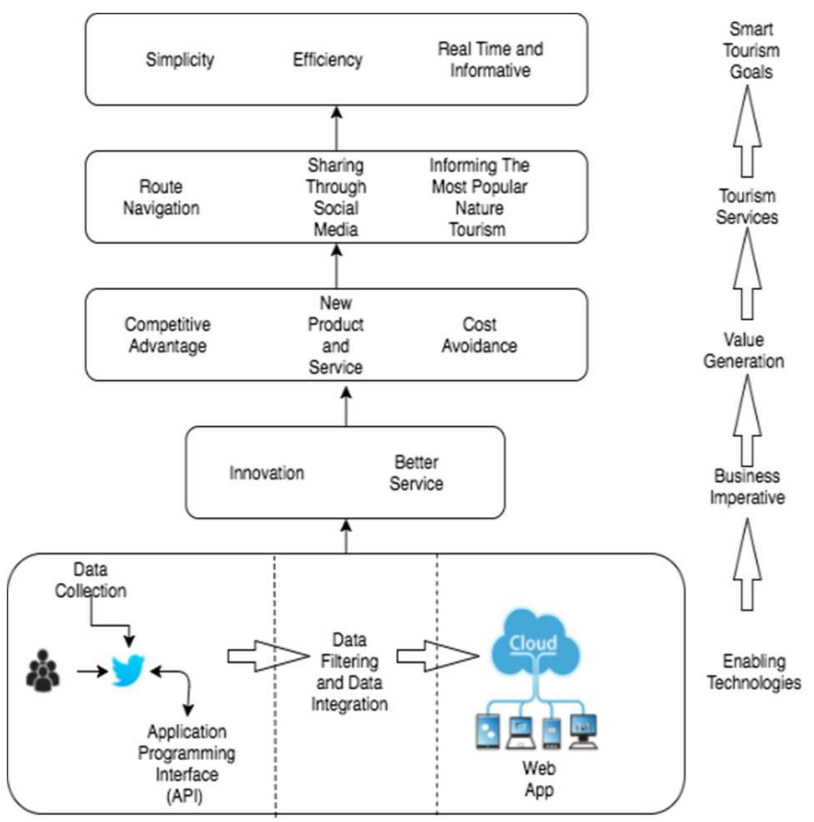

Figure 5. Smart Tourism Architecture 


\section{The First Layer}

The first layer is used to define the purpose of smart tourism that is simplicity, efficiency, real time, and informative. Simplicity is the ease of use of the system, the user does not need to install and does not require manual book for its operation. In smart tourism, no database is required. The system only uses cloud computing for data processing, so it is more efficient. The most important aspect of smart tourism is able to display data information in real time and up-to-date.

\section{The Second Layer}

The second layer is related to the services presented by the smart tourism. The main service of smart tourism is route navigation. The system can direct users from the current location to the destination location. Smart tourism integrated with google maps. In addition, users can share information to social media such as facebook and twitter. Smart tourism can assess the popularity of a tourist destination with a lot of like on the tweet postings, so that the existence of this service is expected to facilitate tourists in determining the best sights for them.

\section{The Third Layer}

The third layer represents the value of what new services are applied to smart tourism system so that it is different from other systems. The new values are applied is able to increase competitive advantage, new product and service, and cost avoidance.

Competitive advantage that can be taken on smart tourism is the assessment on the place of tourist destinations, it can affect the place of tourist managers to improve their services. This can be beneficial for the tourist side too.

The new services in smart tourism are based on the concept of CPSS, where the system emphasizes social aspects, relating to how the system can affect users and users can influence other users. Smart tourism is a publicly accessible system. Smart tourism can be accessed free of charge, without any time restrictions. Users not only save costs but also time in accessing tourist information.

\section{The Fourth Layer}

The fourth layer describes how a system can provide benefits in the service for the users. The main criterion is the system must be innovative and can provide better service.

\section{The Fifth layer}

In this layer the process described in smart tourism system. The first stage is the collection data, the second stage is the data preprocessing, and the last stage is the data presentation. In the first stage, data collection is done by way of sensing. Sensing is done by using postings on twitter from other users. To be able to integrate and retrieve information contained on twitter then needed API. In the second stage of preprocessing data, at this stage data filtering is done. The data that has been taken and collected will be filtered. The filter is done by not displaying postings that do not have images and information displayed only using natural tourism and bandung hashtag. The purpose of filtering is that the information displayed in accordance with the main purpose of smart tourism itself.

The next stage in the development phase is to do testing. The test carried out is to ensure that every functional aspect of CPSS consisting of cyber, physical, social aspects can run well and smart tourism can provide information related to tourist attractions, routes to locations, rating tourist attractions, and share information with other users through social media such as Facebook and Twitter. Details of the test case scenarios can be seen in (TABLE II).

TABLE II

FUNCTIONAL TESTING OF SMART TOURISM

\begin{tabular}{|c|c|c|}
\hline $\begin{array}{c}\text { CPSS } \\
\text { Aspect }\end{array}$ & Test Class & Description \\
\hline \multirow[t]{2}{*}{$\begin{array}{l}\text { Aspect of } \\
\text { Physical }\end{array}$} & $\begin{array}{ll}\text { No GPS } & \text { or not } \\
\text { active } & \text { current } \\
\text { location } & \\
\end{array}$ & $\begin{array}{l}\text { Deactivate GPS and do not } \\
\text { allow browser to show } \\
\text { locations. }\end{array}$ \\
\hline & $\begin{array}{l}\text { GPS is active and } \\
\text { enable browser to } \\
\text { know location }\end{array}$ & $\begin{array}{l}\text { See the result if gps on the } \\
\text { user's device is active and } \\
\text { browser the browser is } \\
\text { allowed to know the user's } \\
\text { location }\end{array}$ \\
\hline \multirow{4}{*}{$\begin{array}{l}\text { Aspect of } \\
\text { Cyber and } \\
\text { Physical }\end{array}$} & $\begin{array}{l}\text { Display } \\
\text { information related } \\
\text { tourist attractions }\end{array}$ & $\begin{array}{l}\text { Information displayed } \\
\text { must have images and } \\
\text { related to nature tourism in } \\
\text { Bandung }\end{array}$ \\
\hline & $\begin{array}{l}\text { Display } \\
\text { information about } \\
\text { route the tourist } \\
\text { attractions }\end{array}$ & $\begin{array}{l}\text { The test is carried out to } \\
\text { see whether the } \\
\text { coordinates of the tourism } \\
\text { location displayed on } \\
\text { smart tourism are the same } \\
\text { as the actual location } \\
\text { coordinates }\end{array}$ \\
\hline & $\begin{array}{l}\text { Display } \\
\text { information about } \\
\text { rating }\end{array}$ & $\begin{array}{l}\text { Check the number of likes } \\
\text { in smart tourism with the } \\
\text { number of likes tweet } \\
\text { from twiter. }\end{array}$ \\
\hline & $\begin{array}{l}\text { Display route } \\
\text { navigation to tour } \\
\text { place }\end{array}$ & $\begin{array}{l}\text { Match the route of tourist } \\
\text { attractions with Google } \\
\text { maps by taking the user's } \\
\text { location and destination of } \\
\text { the tourist attractions. }\end{array}$ \\
\hline $\begin{array}{l}\text { Aspect of } \\
\text { Cyber and } \\
\text { Social }\end{array}$ & $\begin{array}{l}\text { Sharing } \\
\text { information } \\
\text { social media }\end{array}$ & $\begin{array}{l}\text { Share information on } \\
\text { facebook or twitter. }\end{array}$ \\
\hline
\end{tabular}

\section{Deployment}

After all test during development stage success, the next step is determined the environment where the application process should be placed. In deployment process, all source or information of application is public, so there is no privacy information is violated. The source of smart tourism application itself is stored in web hosting service. To access smart tourism, an internet connection is needed on the device used. 


\section{RESULT AND DISCUSSION}

In this section, the results and discussion will be presented in the form of evaluations of developed smart tourism. The component of CPSS smart tourism system, which consists of aspects of cyber, physical aspects, and social aspects.

\section{A. Cyber Aspect}

Cyber aspect is an aspect that includes system connection to internet and cloud computing. The protocol used is Hypertext Transfer Protocol (HTTP) to retrieve and request information. Cloud servers used on smart tourism are integrated directly from twitter using API, so it does not require a local database to get information and using google API to inform position from user.

\section{B. Physical Aspect}

Physical aspects can be support components of smart tourism, that are global positioning system (GPS), device, and human. Where sensors, devices, and humans are interconnected with each other. GPS is a tool can be used to gain information about the position of the existence of tourists and know the coordinates of tweet location, so with the GPS it will make it easier to guide tourists to to go to tourist destinations.

Another component that is inseparable from CPSS is the sensor. Sensor is a tool that serves to detect a change in the system environment. The sensors or actuators used in smart tourism are human. Humans can be used as a physical sensor where when humans are doing post and like on tweet and the system will capture it as unprocessed data, then it will be processed into useful information with the filtering process. The information captured is the actual information related to tourism in Bandung.

\section{Social Aspect}

Social aspects of smart tourism are the data displayed comes from social media twitter. In addition, with smart tourism, tourists can exchange information about tour place through social media such as twitter and facebook. The usefulness of social aspects with the implementation of CPSS, is how the information displayed and exchanged can influence other travelers to visit or assess the quality of the sights based on their respective experience. The result and evaluation of smart tourism system can be seen in (TABEL III,TABEL IV, TABEL V).

TABEL III

Result and Evaluation In Physical Aspect

\begin{tabular}{|l|lr|l|}
\hline Test Class & Results & Evaluations \\
\hline $\begin{array}{l}\text { No GPS or } \\
\text { not active } \\
\text { current }\end{array}$ & $\begin{array}{l}\text { Smart tourism } \\
\text { docation }\end{array}$ & page & $\begin{array}{l}\text { GPS is very necessary to } \\
\text { show the user's current } \\
\text { location, without GPS, } \\
\text { smart tourism cannot } \\
\text { provide directions to tourist } \\
\text { sites. If device that used by } \\
\text { users do not have GPS or } \\
\text { don't activate GPS or } \\
\text { unable browser to know }\end{array}$ \\
\hline
\end{tabular}

\begin{tabular}{|c|c|c|}
\hline & & $\begin{array}{lcc}\text { location, } & \text { then } & \text { smart } \\
\text { tourism } & \text { displays } & \text { blank } \\
\text { page. }\end{array}$ \\
\hline $\begin{array}{l}\text { GPS is } \\
\text { active and } \\
\text { enable } \\
\text { browser to } \\
\text { know } \\
\text { location }\end{array}$ & $\begin{array}{l}\text { Smart tourism will } \\
\text { show the marker } \\
\text { that show the } \\
\text { coordinate of } \\
\text { users. }\end{array}$ & $\begin{array}{l}\text { - Smart tourism system } \\
\text { can accurately display } \\
\text { the coordinates of the } \\
\text { position of tourists or } \\
\text { actual position from } \\
\text { user. } \\
\text { - Sometimes, the } \\
\text { geolocation taken from } \\
\text { the Google API does } \\
\text { not display the } \\
\text { coordinates of the } \\
\text { location correctly, this } \\
\text { is because the GPS } \\
\text { sensor has not been } \\
\text { calibrated and the error } \\
\text { data is taken from the } \\
\text { google server }\end{array}$ \\
\hline
\end{tabular}

TABEL IV

Result and Evaluation in Physical and Cyber Aspect

\begin{tabular}{|c|c|c|}
\hline Test Class & Results & Evaluations \\
\hline $\begin{array}{l}\text { Display } \\
\text { information } \\
\text { related } \\
\text { tourist } \\
\text { attractions }\end{array}$ & $\begin{array}{l}\text { Smart tourism } \\
\text { displays } \\
\text { information } \\
\text { about nature } \\
\text { tourism in } \\
\text { Bandung }\end{array}$ & $\begin{array}{l}\text { Evaluation from the result, smart } \\
\text { tourism just displays } \\
\text { information about nature } \\
\text { tourism from the API twitter that } \\
\text { has an image. So, if a tweet post } \\
\text { doesn't have an image then it } \\
\text { won't be displayed. This is to } \\
\text { ensure that the information will } \\
\text { be more reassured by the } \\
\text { presence of the image of tour } \\
\text { place. }\end{array}$ \\
\hline $\begin{array}{l}\text { Display } \\
\text { information } \\
\text { about route } \\
\text { the tourist } \\
\text { attractions }\end{array}$ & $\begin{array}{l}\text { Smart tourism } \\
\text { can show } \\
\text { location of the } \\
\text { tour place }\end{array}$ & $\begin{array}{l}\text { - Coordinate location displayed } \\
\text { in system is (-6.816599, } \\
107.309462) \text { and coordinate } \\
\text { real location is (-6.816599, } \\
107.619462) \text {. So that the } \\
\text { system can accurately display } \\
\text { route the location. } \\
\text { - The other case, the result } \\
\text { shows the coordinates of the } \\
\text { tour place are not as same as } \\
\text { the actual coordinates of the } \\
\text { tour place. Destination tour } \\
\text { place is (-7.800330, } \\
110.365970) \text {, While the actual } \\
\text { coordinate is on (-6.816599, } \\
107.619462) \text {. } \\
\text { Evaluation from the results is } \\
\text { sometimes, coordinate } \\
\text { location of the tour place can't } \\
\text { be matching with the real } \\
\text { coordinate of the tour place } \\
\text { because the data obtained } \\
\text { from twitter refers to the } \\
\text { location of the user when } \\
\text { posting a tweet, so the }\end{array}$ \\
\hline
\end{tabular}




\begin{tabular}{|l|l|l|}
\hline Test Class & Results & Evaluations \\
\hline $\begin{array}{l}\text { Display } \\
\text { information } \\
\text { about rating } \\
\text { tour place }\end{array}$ & $\begin{array}{l}\text { Smart tourism } \\
\text { can display } \\
\text { rating from } \\
\text { tour place. }\end{array}$ & $\begin{array}{l}\text { The number of ratings shown on } \\
\text { smart tourism are taken based on } \\
\text { the number of likes on tweet } \\
\text { posts, where the number of likes } \\
\text { on Twitter posts is the same as } \\
\text { what is displayed on the system. }\end{array}$ \\
\hline $\begin{array}{l}\text { Display } \\
\text { route } \\
\text { navigation to } \\
\text { tour place }\end{array}$ & $\begin{array}{l}\text { Smart tourismation } \\
\text { can display } \\
\text { the navigation } \\
\text { of the tour } \\
\text { place }\end{array}$ & $\begin{array}{l}\text { If the user's coordinates and the } \\
\text { coordinates of the tourist } \\
\text { attractions have been obtained } \\
\text { from the Google API and } \\
\text { Twitter API, smart tourism will } \\
\text { display maps from Google and } \\
\text { show the route to the tourist } \\
\text { destination. }\end{array}$ \\
\hline
\end{tabular}

TABEL V

Result and Evaluation In Cyber AND Social AsPeCt

\begin{tabular}{|l|l|l|}
\hline Test Class & Results & Evaluations \\
\hline $\begin{array}{l}\text { Sharing } \\
\text { information } \\
\text { on social } \\
\text { media }\end{array}$ & $\begin{array}{l}\text { Users can } \\
\text { share } \\
\text { information } \\
\text { through social } \\
\text { media they } \\
\text { have } \\
\text { (Facebook } \\
\text { and Twitter) }\end{array}$ & $\begin{array}{l}\text { information with other users, the } \\
\text { information shared is the same } \\
\text { smart tourism and users can add } \\
\text { other captions to make it more } \\
\text { interesting. }\end{array}$ \\
\end{tabular}

The result of the third test class and fifth class, display information and rating a tour place, as in (Figure 6) below.

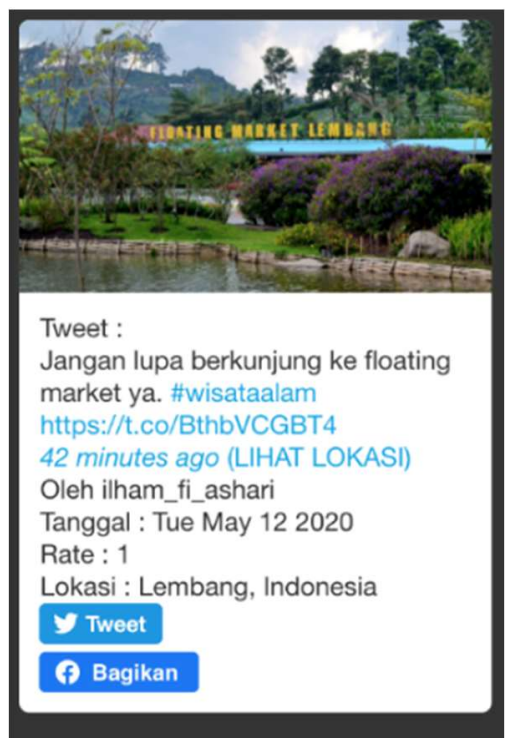

Figure 6. Information and rating tourist attractions on smart tourism

\section{CONCLuSION}

CPSS concept is very useful to optimize interaction between human, system, and how they interact each other. Smart Tourism can influence other travelers to visit the new tour place in Bandung because the information came from social media, where every user can exchange their opinions and give feedbacks to others. The review of tweet also affects satisfaction and experience of tourists towards attractions that had he visited.

By implementing smart tourism tourists will get information such as location, route, images, rating, captions of tourist attractions, and the most important thing is to be able to exchange information with others faster and easier. Smart tourism is more flexible because it is web based and does not depend on the operating system used, does not require database storage, does not take up storage space, and is free. Tourists can access smart tourism anytime and anywhere as long as they are connected to the internet network.

The success of the implementation using CPSS depends on the user or social aspects of CPSS. If a user shares information related to travel appropriately, then information captured by other users will also be correct. The accuracy of the GPS sensor determines location accuracy. Sometimes the GPS sensor does not precisely capture the user's location when posting travel information. This is influenced by the device and ISP used by the user.

This paper only focused on testing CPSS aspect. But, for the future research, there are still many kinds of that can be improved, such as improving location accuracy and can be tested right at all locations in Indonesia.

\section{DAFTAR PUSTAKA}

[1] F. K. K. Putra, P. Saepudin, E. Adriansyah, and I. G. A. W. Adrian., 2018. "Digital Tourism: A Content Analysis of West Java Tourism Websites," J. Indones. Tour. Dev. Stud., vol. 6, no. 2, pp. 73-84.

[2] Y. A. Ghani.,2017. "Pengembangan Sarana Prasarana Destinasi Pariwisata Berbasis Budaya di Jawa Barat," J. Pariwisata, vol. IV, no. 1, pp. 22-31, 2017.

[3] R. C. Utami and D. Hartono., 2016. "Analisis Daya saing Harga Pariwisata Indonesia: Pendekatan Elastisitas Permintaan," $J$. Kepariwisataan Indones., vol. 11, pp. 93-118,

[4] M. Antara and M. S. Sumarniasih., 2017. "Role of Tourism in Economy of Bali and Indonesia," J. Tour. Hosp. Manag., vol. 5, no. 2, pp. $34-44$.

[5] Natalia, S. Bianca, and I. A. Pradipta., 2019. "Analysis User Acceptance of Wonderful Indonesia Application Using Technology Acceptance Model (case study: Indonesian Ministry of Tourism)," Proc. 2019 Int. Conf. Inf. Manag. Technol. ICIMTech 2019, vol. 1, no. August, pp. 234-238.

[6] M. Yudhistira and D. Octavia., 2016. "analysis of attraction bandung as a tourism destination based memorable tourism excperience," in $e$ proceeding Telkom University, vol. 3, pp. 1243-1249.

[7] K. Boes, D. Buhalis, and A. Inversini., 2015. "Conceptualising Smart Tourism Destination Dimensions," Springer Int. Publ. Switz., no. February, pp. 391-403.

[8] A. Dalli and S. Bri., 2016. "Design of Electronic Ticket System for Smart Tourism," in 12 th Internation Confrerence on Signal-Image Technology and Internet-Based Systems, pp. 490-492.

[9] S. L. Joseph et al., 2015. "Being aware of the world: Toward using social media to support the blind with navigation," IEEE Trans. Human-Machine Syst., pp. 1-7. 
[10] R. D. H. Tobing., 2015. "Mobile tourism application for Samosir Regency on Android platform," in 2nd International Symposium on Technology Management and Emerging Technologies, ISTMET 2015 - Proceeding, 2015, pp. 249-253.

[11] J. N. Nyaboro, J. Park, D. Rashed, and A. Eltawil., 2019. "M-Tour : A Smart Design Tourism Application for a Destination Competitiveness by a Design Thinking Approach," in Twenty-Third Pacific Asia Conference on Information Systems, China.

[12] F.-Y. Wang., 2010. "The Emergence of Intelligent Enterprises: From CPS to CPSS",

[13] J. Zeng, L. T. Yang, M. Lin, H. Ning, and J. Ma., 2016. "A survey: Cyber-physical-social systems and their system-level design methodology," Futur. Gener. Comput. Syst.

[14] Z. Liu, D. S. Yang, D. Wen, W. M. Zhang, and W. Mao., 2011. "Cyber-physical-social systems for command and control," IEEE Intell. Syst., pp. 92-96.

[15] S. Wang, A. Zhou, M. Yang, L. Sun, C. H. Hsu, and F. Yang., 2016 "Service Composition in Cyber-Physical-Social Systems," IEEE Trans. Emerg. Top. Comput., pp. 1-11.

[16] J. J. Zhang et al., 2018. "Cyber-physical-social systems: The state of the art and perspectives," IEEE Trans. Comput. Soc. Syst., vol. 5, no. 3 , pp. 829-840.

[17] H. J. Bullinger, K. P. Fähnrich, and T. Meiren., 2003. "Service engineering - Methodical development of new service products," Int.
J. Prod. Econ., vol. 85, no. 3, pp. 275-287.

[18] J. Cardoso, K. Voigt, and M. Winkler., 2009. "Service engineering for the internet of services," Lect. Notes Bus. Inf. Process., vol. 19, pp. $15-27$.

[19] Silvia, Suhardi, and P. Yustianto., 2016. "Business process improvement of district government innovation service: Case study Cimahi Tengah District of Cimahi," in 2016 International Conference on Information Technology Systems and Innovation, ICITSI 2016 Proceedings.

[20] Hermawan and R. Sarno., 2012. "Developing distributed system with service resource oriented architecture," Telkomnika, vol. 10, no. 2, pp. 389-399.

[21] Suhardi, R. Doss, and P. Yustianto., 2015. "Service engineering based on service Oriented Architecture methodology," Telkomnika (Telecommunication Comput. Electron. Control., vol. 13, no. 4, pp. 1466-1477.

[22] P. Clements, D. Garlan, R. Little, R. Nord, and J. Stafford., 2003. "Documenting software architectures: Views and beyond," in Proceedings - International Conference on Software Engineering, vol. 03.

[23] L. Bass, P. C. Clements, and R. Kazman., 1997. Software Architecture in Practice. 3 rd ed. Addison-Wesley. 